\title{
Argumentation in Demosthenes's speech Against Timocrates
}

\author{
Dániel Seres \\ (Eötvös Loránd University, Budapest)
}

\begin{abstract}
The current study has three objectives. First, it provides an in-depth analysis of the argumentation of the oration Against Timocrates. Second, the analysis focuses on the issues of textual criticism that arose in the 19th century and have been debated ever since. Approaching the problems from a new perspective - augmenting the convincing arguments put forward by E. M. Harris with the analysis of the argumentation - the study argues that the two halves of the speech are in fact parts of a well-planned and precisely edited whole, and that the integrity of the text needs not to be questioned. Third, it supports Rhodes's and Harris's work providing a case-study of how a speech could be constructed to ensure that the arguments are wide-ranging in method and relevant from a legal point of view.
\end{abstract}

\section{Keywords}

Demosthenes; Against Timocrates; ancient Greek oratory; argumentation

This study was supported by the ÚNKP-20-4 New National Excellence Program of the Ministry for Innovation and Technology from the source of the National Research, Development and Innovation Fund. I would like to thank my supervisor Professor György Németh as well as the two anonymous reviewers for their constructive comments. Any remaining mistakes are my own. 
In 354/353 BC, three Athenian envoys - Androtion, Glaucetes and Melanopus travelled to Mausolus, the Satrap of Caria. ${ }^{1}$ According to the second argument written to the speech, the delegation was sent to Mausolus to complain about the injustices he perpetrated against the Greek islands. However, after losing the Social War, this claim is highly unlikely. As a result, the academic consensus is that instead of supporting the former rebels, the envoys were sent to improve Athenian relations with the Persian Empire through Mausolus. ${ }^{2}$

Two captains, Archebius and Lysitheides, led the ship on the mission. ${ }^{3}$ During the voyage, the delegation ran into a merchant ship from Naucratis, the cargo of which the delegation seized. ${ }^{4}$ On returning to Piraeus, the envoys sold the cargo for nine and a half talents $\left(=57,000\right.$ drachmae). ${ }^{5}$ However, rather than turning the income over to some authority, they kept it for themselves. The merchants then applied to the Athenian Ecclesia for the return of their seized property. The Assembly rejected the request, considering the ship's cargo the spoils of war, as Athens considered Egypt an enemy at the time. ${ }^{6}$ The envoys continued to hold onto the money, despite laws requiring that they donate it to the polis and the treasuries of various gods:

"...when they have seized and still retain tithes of the goddess and the fiftieths of the other gods instead of returning them and that they have stolen public property that belongs to you."

This led Aristophon to propose to the Assembly that investigators (zêtêtai) should be appointed to lead an inquiry into which citizens may be holding state or sacred funds. ${ }^{8}$

1 Dem. 24.12. Mausolus was the Satrap of Caria, 377-353/352. For a comprehensive overview of his life, see Hornblower (1982).

2 The problem was first raised by Cawkwell (1962: pp. 48-49) and Harding (1976: pp. 195-196). Newer research has accepted their logical conclusions, cf. Hornblower (1982: p. 215, note 271); Badian (2000: p. 22); Harris (2018: p. 123, note 55). For a history of the Second Athenian League and the Social War, see Cargill (1981); Sealey (1993: pp. 102-136); Radicke (1995: pp. 11-20); Rhodes (2006: pp. 226-243).

3 Dem. 24.11. It is possible that the fragmentary honorary decree number IG II $^{2} 150$ praises the deeds of this delegation. The name Lysitheides - $\Lambda v \sigma i \theta \varepsilon[i \delta \eta \nu \ldots$ - can be completed with some certainty, but uncer-

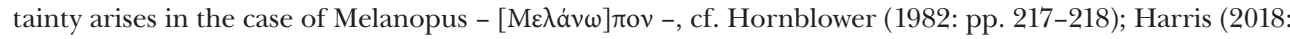
p. 123 , note 55).

4 Sealey (1993: p. 106) raises the possibility that the merchants from Naucratis were not victims of simple piracy but were acted against based on orders from the King of Kings. In this case, the Athenians intervened as aggressors against the Egyptians who were in rebellion against the Great King, a political position that could have improved Athenian-Persian relations. Badian (2000: p. 23) maintains the theoretical possibility. On the Persian-Egyptian conflict, see - in addition to the works cited above - Diod. Sic.16.40.1-16.52.8. In connection with the difficulties of dating the campaigns see - in the context of $O n$ the Liberty of the Rhodians - Radicke (1995: pp. 36-38) in opposition to him Lane Fox (1997: pp. 187-191).

5 Dem. 24.11., see also the other (hetera) hypothesis.

6 Dem. 24.12.

7 Dem. 24.120. All quotations from the speech are cited in Edward Harris's translation.

8 Dem. 24.11. 
Euctemon then gave information against the commanders of the ambassadors' ship, Archebius and Lysitheides, and the Council discussed the case. ${ }^{9}$

Androtion, Glaucetes, and Melanopus then admitted that they had the 57,000 drachmae and not the ship's captains. Euctemon then proposed a decree that the ship's captains should cover the debt but allowed them to apply to those in possession of the money in question. Should a dispute arise between the parties, who should pay the specified amount would be decided in a diadicasia. ${ }^{10}$ However, Euctemon's proposal also contained a harsh punishment: 57,000 drachmae gained as spoils were to be paid alongside a hefty fine:

“... but when Androtion had to return the money, both sacred and public, he stole from the city long ago, he then passed a law designed to rob twice this amount from the city and ten times this amount from the gods." 11

Based on these ratios, the initial payments to the various treasuries would have been: 5,700 drachmae to Athena, 1,140 drachmae to the other deities, and 50,160 drachmae to Athens state treasury; but according to Euctemon's decree, these would have been as follows: 57,000 drachmae to Athena, 11,400 drachmae to the other deities and 100,320 drachmae ${ }^{12}$ to the treasury of Athens. It appears that the ambassadors would have been willing or able to pay the original amount but were unable to cover the fine. In response, they challenged the decree and brought a graphē paranomōn $n^{13}$ suit against Euctemon. However, the courts acquitted him; thus, the decree he had submitted remained in force. Consequently, Androtion and his associates were convicted in the last month of the year 354/353 BC, in the month of Scirophorion. ${ }^{14}$

After the above, Timocrates submitted his law in the first month of the following year, Hecatombaion, in a hurry. ${ }^{15}$ The act can be summarised as follows: an Athenian citizen

9 Dem. 24.11-12

10 Dem. 24.13. On diadicasia, see Rubinstein (2005: pp. 134-135) and Maffi (2005: p. 264).

11 Dem. 24.111. The same appears in Dem. 24.82.

12 Dem. 24.15 The double multiplier applied to the amount to be paid to the state treasury is also noted here.

13 On the type of suit, see Hansen (1999: pp. 205-212).

14 Dem 24.14-15.

15 Dem. 24.39-40., 71. Over the last few years, a debate between Canevaro and Hansen has unfolded on the nomothesia procedure of the Athenian legislature, see Hansen (2016; 2019). cf. Canevaro (2013; 2018; 2020). Hansen (2019: p. 454) accepts the procedure outlined by Canevaro (2013: p. 94). The debate primarily revolves around a possible statutory review that may have taken place at the first session of the Ecclesia in the year - on 11 Hecatombaion - which hinges on the authenticity of the document noted in the Dem. 24.20-23 caputs, which Canevaro (2013: pp. 94-102; 2018; 2020) consistently considers to be a later interpolation - even if the author of the text was very highly trained cf. Canevaro (2013: p. 102) opposed to this Hansen $(2016 ; 2019)$ considers it to be authentic and questions Canevaro's methodology and conclusions. Hansen (2019: p. 455) criticizes Canevaro's third methodological principle. He does not consider the principle of parallel inscriptions to be feasible or one to be followed. Canevaro (2020) convincingly refutes all of Hansen's previous counterarguments. The latest translator of the text, Harris (2018: pp. 110-111, note 13), accepts Canevaro’s arguments over Hansen's. Canevaro (2018: pp. 121-122) 
- tax farmers, tax collectors and guarantors were an exception ${ }^{16}$ - that had previously been sentenced to imprisonment or subsequently imprisoned due to owing a public debt, ${ }^{17}$ should have the right to appoint guarantors ${ }^{18}$ who are approved by the Ecclesia, ${ }^{19}$ to pay the debt by the ninth prytany ${ }^{20}$ and avoid imprisonment. ${ }^{21}$ Should this not happen, the freed individual would be imprisoned and the guarantors' property confiscated. ${ }^{22}$ In response, Diodorus submitted a graphē nomon mè epitêdeion theinai case ${ }^{23}$ against Timocrates, and Demosthenes wrote the speech. ${ }^{24}$

A two-sided evaluation of the structure of Against Timocrates has developed in the literature. The first half of the speech (Dem. 24.1-109), in which Demosthenes made his legal arguments against the law proposed by Timocrates, is generally praised and considered an outstanding invention in applying legal arguments. ${ }^{25}$ However, earlier research has been harsher with the second half of the speech (Dem. 24.110-218). A lasting debate arose in the 19th century around the contradiction that seemed to arise from the fact that at the beginning of the speech, Diodorus states that Androtion and his companions had not paid the debt in question, but then says that Timocrates will claim they have paid it, at the end of the speech. ${ }^{26}$ The contradiction seemed insoluble, and questions about the authenticity of the oration arose. Previous research has argued that two ver-

also implies support for his position from the wider academic community in his acknowledgements. The following footnotes summarise mentions of certain parts of the law in the speech. the members of the council - cf. Dem. 24.144. Harris (2018: p. 218, note 108), however, lists this stipulation in the summary of the law. This is presumably based on a counterargument made by Timocrates in connection with the prohibition on prison sentences - cf. Dem. 24.144-148. - but the stipulation is never mentioned in connection with Timocrates's law, meaning Harris's amendment is questionable. Libanius also only mentions guarantors, cf. Lib. Hyp. 23.2.

19 Dem. 24.79., 84. Harris notes (2018: p. 108, note 4) that this is necessary in order to examine the financial background of those providing the surety. Only a person with the appropriate financial background could be designated as guarantor. Demosthenes seems untrusting of the ecclesia's judgement, cf. Dem. 24.85.

20 Dem. 24.87-88, 93, 98, 169.

21 Dem. 24.46., 64., 77., 79., 84., 87., 93., 103.

22 Dem. 24.87., 89

23 For the most recent overview of the suit type see Canevaro (2016: especially a summary on pp. 54-56). In the case in question, the goal was to abolish a previous law without submitting a new one because errors had been made in the legislative process or the new regulation was contradictory to existing laws. Furthermore, the prosecutor(s) also had the opportunity to request a prison sentence for the citizen who submitted the law, if less than a year had passed since it was passed (Dem. 20.144). Such a conviction was possible if prosecutors could prove pre-mediated intent to submit a law that was contradictory to existing legislations.

24 Lib. Hyp. 23.

25 MacDowell (2009: p. 194) evaluation is a good example of this: "The arrangement of the legal arguments is admirable. Each relevant law is read out, and it is shown how Timocrates's law conflicts with it or diverges from it. Demosthenes here is inventing or developing a new and cogent method of proofs; as far we know, no earlier speech had used the documentary evidence of laws so fully and cogently." 
sions of the speech had been compiled, and this version had survived for posterity - the idea that Diodorus did not perform the speech was also floated. ${ }^{27}$ The almost word for word repetition of phrases used in Against Androtion was seen as an additional argument supporting compilation..$^{28}$

However, the contradictions can be resolved with relative ease. Schaefer has already noted that the function of the second half of the speech - as a result of the type of suit - is to convince the jury that Timocrates wanted to cause deliberate harm to the Athenian state. ${ }^{29}$ As will be seen below, Androtion plays a decisive role in Diodorus's argumentation - he aims to use this connection to prove that Timocrates proposed the law on Androtion's behalf and thus caused deliberate harm to the Athenian state, and seeks a more severe punishment for Timocrates on these grounds. It makes perfect sense that he repeats previous accusations in an attempt to cast the worst possible light on Androtion and Timocrates, while also drawing the audiences attention towards the repetitions..$^{30}$ Furthermore, Harris convincingly argues that the issue of debt is simply not a strong enough rhetorical base. ${ }^{31}$ Diodorus was aware that he must address the issue of the debt being paid but - presumably - could not refute the fact that it had been paid. He thus chose to emphasise that this was not the issue the jurors would have to decide on and thus avoids wasting the audiences time - while, in fact, he is simply hoping that the jury does not notice the obfuscation. ${ }^{32}$

The following structural analysis shall aim to supplement Harris's arguments and draw attention to the fact that the two halves of the speech are actually part of a wellplanned, precisely structured whole, i.e. the integrity of the text needs not to be questioned. Diodorus's arguments can be divided into four categories: legal, political, sacral, and moral. Through the specific legal arguments, Diodorus aimed to prove that Timocrates had broken the laws governing new legislation in Athens on several counts. Diodorus gives these arguments in the first half of the speech, and only reflects on them through short references in the second. The connection between the two parts of the speech is, indeed, looser in this regard. The political arguments or those pertaining to the political system are directed at how the proposed law was against the best interests of Athenians. As will be seen, these arguments reach their height at the end of the first half of the speech. Nevertheless, Diodorus successfully maintains and bolsters them with new examples in the second part of the oration. The sacral and moral arguments, on the other hand, serve a dual purpose: on the one hand, they add weight to the legal and

27 Schaefer (1885: pp. 388-389) considers the oration was spoken; Blass (1893: Vol. III.1, p. 281) and Wayte (1893: pp. xlii-xliv) do not rule out the possibility that the speech was not given; Navarre-Orsini (1954: p. 117) consider it a compilation from after Demosthenes's death; MacDowell (2009: pp. 195-196) considers it unfinished.

28 Dem. 24.47-56., cf. Dem. 24.160-168; Dem. 24.57-64., cf. Dem. 24.167-171; Dem. 24.65-78., cf. Dem. 24.172-186.

29 Schaefer (1885: pp. 387-388).

30 Dem. 24.159.

31 Harris (2018: p. 117).

32 Dem. 24.189. 
political arguments, and on the other hand, by defaming Timocrates and Androtion, they provoke dislike in the jury, to prove Timocrates's intent more easily. That is, should the case be successful, not only would the law be repealed, but Timocrates punished. The sacral arguments fame the entire speech, they reach their peak near the end of the oration. Moral arguments dominate the second half of the speech. It is best to treat the introductory caputs as a unit so that the base of Diodorus's arguments can be seen clearly. The latter parts of the speech, however, should be examined according to the four types of arguments above.

At the beginning of the speech, Diodorus repeats the three main charges: Timocrates's law is in opposition to laws already in force, it does not serve the best interests of the city, and that Timocrates acted intentionally, for the benefit of others, and received money in return..$^{33}$ The list also notes that Timocrates had undermined the operation of the courts. ${ }^{34}$ While not a charge in itself, only an element of the second main point, Diodorus mentions it specifically to build resentment of Timocrates in the jury. He then states that while Timocrates was enriched through the new law, he is risking 1000 Drachmae on the lawsuit. With this, Diodorus aims to distance himself from Timocrates at the beginning of the speech and stress that his goal is to protect the jurors - i.e., the citizens of Athens - from this injustice. The personal grievances towards Androtion that played a role in the suit are only mentioned later. ${ }^{35}$ Androtion had previously unsuccessfully brought a charge of impiety against Diodorus, as he recalls:

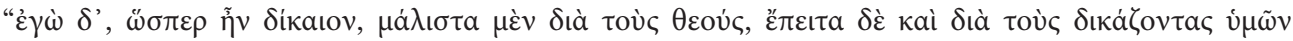

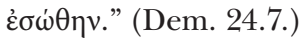

"I owe my safety, which I justly deserved, primarily to the gods, then also to those of you judging the case."
}

On the one hand, this sentence is another gesture towards the jurors, another attempt to secure their goodwill. He invites them to realise their crucial role as the decision-makers, which may also be a technique of putting emotional pressure on them. On the other hand, it gives the impression that he, Diodorus, benefits from the grace of the gods, while Androtion does not. Furthermore, Diodorus named Androtion enemy of the gods

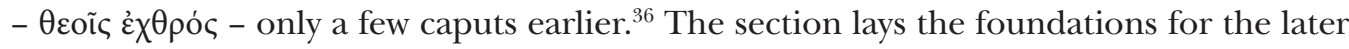
sacral arguments and draws a clear contrast between the accuser and the accused, i.e. he implicitly instructs the judges about how to feel and think of Diodorus and Androtion. Diodorus only mentions his previous political roles - tax collection, melting down of sacred vessels - in passing. As these are not directly connected to the law and serve only to besmirch Timocrates, they will be detailed in the second half of the speech. However, he notes that Androtion is in illegal possession of both state and sacred funds. This is

Dem. 24.1-3. 
the specific connection to Timocrates. Diodorus uses this connection in an attempt to prove that Timocrates submitted his law directly because of the debt in question. ${ }^{37}$ After summarising the immediate background of the lawsuit, he says of Timocrates:

"There was certainly no need at all for any law. Up to this point Timocrates here had done you no wrong. After this he became responsible for all the things previously mentioned." (Dem. 24.14.)

However, the statement is not entirely true in this form. The second half of the speech includes scathing criticism of Timocrates's previous support for Androtion. He wants to give the impression that Timocrates had not previously harmed the city, and thus Diodorus is impartial towards him, which is why the jurors must take the accusations that are being made seriously.

\section{Legal arguments}

Diodorus first focuses on the time frame of the law's proposal. The Assembly held its first session of the year on 11 Hecatombaion, and then, Timocrates submitted and pushed through his bill the next day, completely unexpectedly. ${ }^{38}$ In doing so, he unquestionably went against the legislative practice in two counts. He did not placed the proposal in front of the monument of the Eponymous Heroes, and the Ecclesia could have only voted on the law at its Third sitting after the submission. ${ }^{39}$ It was the Panathenaea that created the opportunity for his quick actions. A decree submitted by a certain Epicrates made it possible for legislators to be convened the following day to secure the required financial resources should anything threaten the smooth running of the Panathenaea. Timocrates took advantage of this decree to accelerate the passage of his proposal. However, as Diodorus explains at length, ${ }^{40}$ the proposed law has no connection to the Panathenaea. Thus, Timocrates must have committed a procedural error and abused the "loophole" hidden in the decree.

After proving that the time frame for passing a new law had been violated, Diodorus summarises and praises the law that governs the passing of new laws. ${ }^{41} \mathrm{He}$ then has Timocrates's law read and lists six arguments as to why it contradicts laws already in effect.

Diodorus first tries to convince the judges that Timocrates's law is retroactive, as it would extend the modification of sentences to already closed cases. ${ }^{42}$ This is clearly an

37 Dem. 24.9.

38 Dem. 24.26.

39 Dem. 24.25., cf. Canevaro (2013: pp. 89-90).

40 Dem. 24.28-29.

41 Dem. 24.32-40.

42 Dem. 24.42. This argument is repeated at the end of the speech, cf. Dem 24.194. 
exaggeration. Subsequent commutation or even total pardons were not unknown in Greek legal thinking. ${ }^{43}$

However, the second argument is valid. Diodorus quotes the law on the cancellation of debts owed to the state or their payment in installations, according to which any amendment must be discussed first by the council and then by the Ecclesia. ${ }^{44}$ This did not happen in the case of Timocrates's law. ${ }^{45}$ Harris and MacDowell argue that the argument is misleading because the law does not cancel debts; it simply commutes the prison sentence if someone can produce surety. ${ }^{46}$ However, Diodorus's argument may be legitimate when considering the spirit of the law. Timocrates's law allows debts to be paid by the end of the ninth prytany and, in essence, restructures these debts. Thus, a parallel can be drawn between it and payment in instalments, as the entirety of the debt is only paid later.

The third argument distorts the facts and cannot be upheld. The cited law forbids sup-

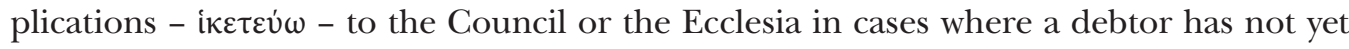
settled his debt. ${ }^{47}$ This is a clever rhetorical trick, as the law prohibits supplications, not laws. ${ }^{48}$ Harris's wording indicates that he does not accept the supplication-bill opposition. ${ }^{49}$ However, he also rejects the argument because the law in question stipulates rules connected to debts, which are not cancelled by Timocrates's, making the law irrelevant in the context. MacDowell and Canevaro's approach rests on stronger legal foundations. The distinction between supplications and laws is easier to defend than the opposition between debt and imprisonment. For in the latter case, if the question is approached from the spirit of the law, then no matter what request the supplicant submits, he is not allowed to submit it until the debt is paid.

The fourth argument seeks to prove that Timocrates violated the law prohibiting the review of court judgments. After summarising the law, Diodorus presents Timocrates as someone who has undoubtedly broken the law:

"Well, now, Timocrates immediately begins his law by violating this rule as if to provide testimony for his own crimes." (Dem. 24.55.)

However, this argument is also just a rhetorical trick. The cited law only states that another judicial proceeding cannot overturn a valid court judgement. In other words,

43 Wayte (1893: p. 124) also noticed this: "The reasoning here is rather absurdly sophistical: the notions of an amnesty, or of a mitigation of statutory penalties, were sufficiently familiar to the Athenians." MacDowell (2009: pp. 187-188) and Harris (2018: p. 135, note 109) agree.

44 Dem. 24.45.

45 Canevaro (2018: p. 92).

46 MacDowell (2009: p. 188); Harris (2018: p. 137, note 112).

47 Dem. 24.50.

48 MacDowell (2009: p. 188); Canevaro (2013: p. 133).

49 Harris (2018: pp. 138-139, note 121). 
Diodorus tries to sell a limitation on the working of the courts as a limitation on the Ecclesia. The Assembly generally had the right to overturn any court ruling. ${ }^{50}$

The fifth argument states that the proposed law affects Athenian citizens differently. However, this again can be drawn into question, something Diodorus knows well:

\begin{abstract}
"You know as well as I do for whose benefit this man introduced his law. But apart from these men, he himself has admitted that he did not enact the same rule for all by adding a special clause excluding tax collectors, lessees, and their sureties." ${ }^{51}$
\end{abstract}

As there are no names in the text of the proposed law, the argument cannot be upheld. Thus, he moves to the passage of the law that lists the exceptions quickly, but no names are given here either, and laws can formulate general exceptions. ${ }^{52}$

The literature considers the sixth argument to be the strongest, ${ }^{53}$ and it seems Diodorus was of a similar opinion. Based on what can be gleaned from the structure of the speech. The last concrete legal argument must be firm and surprising before he moves onto the next section, which aims to prove that the law is not in the best interests of the citizens of Athens. Diodorus began his earlier arguments by summarising each law in question. But he changes strategies for the final argument. The summary of the law is given in the middle of the five-caput-long section and introduced with the following:

\footnotetext{
"To have introduced a law contrary to those passed by others is terrible, but it requires another person to make the charge. But for someone to enact a law in violation of a law he himself enacted earlier places him in the position of being one's own accuser. For you to understand what is happening, the clerk will read to you the law that this man has enacted. I will remain silent. Read it." ${ }^{54}$
}

He even has the clerk repeat the final line $!^{55}$ Both the rhetorical structure and the content of the cited law may have shocked the jurors. Timocrates's previous law had unequivo-

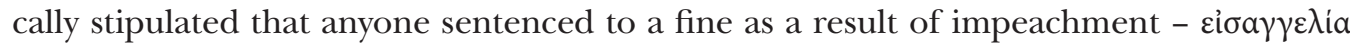
- should remain in prison until the fine has been paid. Although there is no concrete contradiction between the two laws as they govern different legal procedures, the spirits of the two laws are in complete opposition, making the argument the most suggestive of those among Diodorus's concrete legal arguments.

50 Pecorella Longo (2004). Cites Harris (2013b: p. 73, note 34).

51 Dem. 24.59. The argument is repeated several times, cf. Dem. 122., 188., 193.

52 Hansen (1979: pp. 28-29); MacDowell (2009: p. 189); Canevaro (2013: p. 148); Harris (2018: p. 142, note $133)$.

53 MacDowell (2009: pp. 189-190); Canevaro (2013: p. 152); Harris (2018: p. 144, note 137) cites MacDowell statements without comment.

54 Dem. 24.62. This argument returns in caput 199.

55 Dem. 24.64. 


\section{Political arguments}

In parallel with the specific legal arguments, Diodorus builds the image of an irreconcilable opposition between Athenian democracy and Timocrates in four smaller steps. Diodorus uses every tool available to paint Timocrates as a despicable oligarch. At the end of the century, the oligarchic turns - the rule of the Four Hundred in $411 \mathrm{BC}$ and the Thirty Tyrants in $404 \mathrm{BC}$ - evoke the darkest hours of Athenian history. ${ }^{56}$ The trauma of these events was a personal experience for older citizens and was kept alive in younger citizens through the community's collective memory and could thus evoke both fear and hatred. This is why the Athenian experiences of oligarchy are a recurring element of Demosthenes's early speeches, regardless of whether they were performed in front of the Ecclesia or the courts. ${ }^{57}$ Diodorus emphasises that laws are the protectors ${ }^{58}$ of Athenian democracy in the opening section of the speech while listing the charges. The thought reoccurs as a central theme in the closing section of the speech, thus framing Diodorus's argumentation.

"That there is nothing else more responsible for the advantages the city possesses and for our
democratic constitution and freedom than the rule of law, I think no one would deny. Indeed,
this is the very issue before you now: whether the rest of the laws you have enacted against men
who harm the state are to be repealed while this one is to remain in force, or this one is to be
repealed to allow the others to remain in place." 59

Oligarchy as a counterpoint is first raised after the summary of the law on the legislative process. True, the first mention is general and does not name Timocrates directly.

"All these laws have already been in effect for a long time, men of the court, and have often proved themselves beneficial for you. No one has ever denied that they are good, and rightly so. They do not order anything harsh, violent, or oligarchic, but quite the opposite: they command us to act in a generous and democratic way." (Dem. 24.24.)

56 The speech only mentions the Thirty Tyrants and Critias specifically. On the Thirty Tyrants, see X. Hell 2.3.2-2.4.43., Arist. Ath. Pol. 34.3-38.4. for a detailed analysis of the period see Németh (2006). Develin (2003: p. 184) offers a useful starting point for identifying the tyrants.

57 Dem. 22.32., 51-52.: gives the impression that the life and deeds of Androtion are the same as - or in some ways, even more disgraceful - than the cruelty and corruption of the Thirty Tyrants. Dem. 20.15.: He presents Leptines's law as if it restricted the functioning of democracy. Dem. 16.22.: In his speech For the Megalopolitans, he evokes the horrors of the terrors of the Athenian oligarchy to add weight to the Spartan threat. Dem. 15.: one of the defining, central themes of On the Liberty of the Rhodians is the opposition between democracy and oligarchy.

58 Eucrates's law that aimed to prevent the reversion of tyranny in 337/336 BC can be listed here based on its contents - IG II ${ }^{3} 1,320$. However, the provisions limiting the power and authority of the Areopagus were increasingly emphasised, which - most likely - aimed to suppress the political ambitions of Demosthenes and his political allies. For a summary of the debate surrounding the inscription see Rhodes \& Osborne (2007: No. 79). 
Diodorus expands on the idea after the fourth legal argument - regarding the overruling of judicial rulings - creating an explicit opposition. He also cites two laws stating that from $403 \mathrm{BC}$ onwards - that is, since the restoration of democracy - court judgements brought in the years of democracy are valid, while the provisions of the Thirty Tyrants are not. ${ }^{60}$ MacDowell discusses these two laws separately among the legal arguments. ${ }^{61}$ Diodorus aims to support his weak fourth argument with these laws. However, neither of the cited regulations prohibited the Assembly from overruling the courts. This is why the two laws are better listed among political arguments than legal ones. This section of the speech can also be seen as a pre-summary. Diodorus draws an explicit conclusion from his arguments: that the way Timocrates acted is reminiscent of the Thirty Tyrants. He confirms this parallel not much later, clearly presenting Timocrates as an oligarch working against the democratic political system ${ }^{62}$ Diodorus even goes as far as identifying Timocrates with Critias, one of the Thirty Tyrants notorious for his cruelty.

"If Critias, who was a member of the Thirty, passed this law, I think that he would have written and proposed it in the very same way this man has." (Dem. 24.90.)

When, towards the end of the legal arguments, the opposition is strengthened, Timocrates - who is now somewhat considered Critias - is contrasted with the legendary Athenian statesman, Solon. ${ }^{63}$ The Solon-Timocrates juxtaposition permeates the entire speech from this point: Diodorus repeats the idea four times. It first reoccurs at the end of the political arguments, when Diodorus cites the law on thieves, those acting against their parents and those who do not apply for military service, and notes that Timocrates's law gives these vile people the opportunity to avoid imprisonment. ${ }^{64} \mathrm{He}$ then aims to show Timocrates's intentions as corrupt and against the democratic order - as opposed to Solon's honourable nature - by contrasting his proposal with Solon's law on theft ${ }^{65}$ Finally, towards the end of the speech, Diodorus evokes the figures of both Solon and Draco. Diodorus closes his argumentation with the anecdote attributed to Solon that draws a parallel between counterfeiting and the destruction of laws. ${ }^{66}$ To reinforce this series, Diodorus emphasises the oligarchic actions of Timocrates twice more. He calls attention to them once in light of the proposed law. ${ }^{67} \mathrm{He}$ then likens his earlier joint work with Androtion, the collection of the eisphora, to the cruelty of the Thirty Tyrants. Going further, Diodorus considers Timocrates worse than the tyrants, claiming that at

\footnotetext{
60 Dem. 24.56-58.

61 MacDowell (2009: p. 189).

62 Dem. 24.75-76.

63 Dem. 24.102-107.

64 Dem. 24.102-107. He repeats these points in the caputs 117-119.

65 Dem. 24.113-119.

66 Dem. 24.211-214.

67 Dem. 24.152-154.
} 
least people were safe in their own houses during their rule. ${ }^{68}$ With the points raised after the concrete legal arguments, Diodorus seeks to reinforce this opposition, elaborate on it, and evoke hatred in the jurors.

Demosthenes briefly shows that good laws are comprehensible, enforceable, and apply to everyone equally. Timocrates's law, on the other hand, does not meet any of the criteria and is, therefore, against the best interests of Athens ${ }^{69}$ In this section, Diodorus seeks to create the impression that the law would bring complete chaos to Athenian public life, making it impossible for the city to function. The inaccuracy of the first two aspects $^{70}$ - retroactive legislation, overruling the courts - have already been discussed among the legal arguments.

Diodorus's third suggestion that the law does not clarify what happens to the debtor in the period between a judgement being announced and a surety being provided raises a perfectly legitimate point. Diodorus aims to paint the picture that Timocrates created this loophole to favour Androtion and his companions but cannot prove this. ${ }^{71}$

Diodorus puts forward several arguments of an economic nature. First, he rightly points out that the wording of the Timocrates's law is problematic, as it contains the

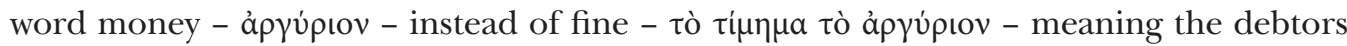
would have to donate much smaller amounts to both the state and sacred treasuries.

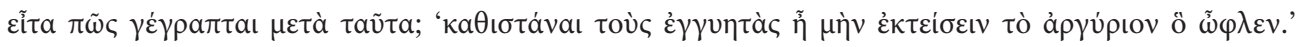

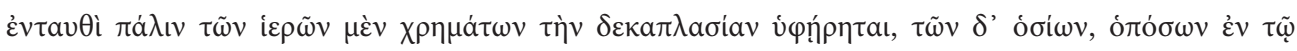

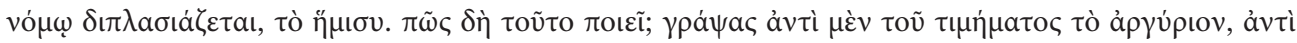

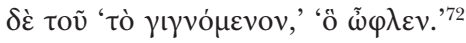

"What, then, is the next clause? 'Provide sureties to pay the money he owed.' Here again he has stolen away the tenfold payment of sacred debts and reduced by half the amount of public debts, which are doubled in the law. How does he do this? By writing 'the money' instead of 'assessed penalty' in one place and 'the amount he owed' instead of 'the total amount' in another."

This accusation is easy to dismiss. Timocrates would only have to claim that these are simply drafting errors and emphasise that money should, in fact, be understood as fine, and he did not want to damage either the state or the deities. ${ }^{73}$ Later Diodorus details the difficulties deferral of payment may cause. The law provides a deferral of payment until the ninth prytany, thus creating a delay in the state's income. In Diodorus's interpretation, the state collapses as official bodies do not meet, and military campaigns are

68 Dem. 24.160-187.

69 Dem. 24.68-70.

70 Dem. 24.71-74., 77-78. He repeats the retrospective nature as an argument in caput 194.

71 Dem. 24.79-81., cf. Harris (2018: p. 149, note 150), by contrast, MacDowell (2009: p. 191) considers this intentional, saying Timocrates could have hoped that by exploiting this loophole, they could avoid imprisonment completely.

72 Dem. 24.82. The same argument is repeated in caput 86.

73 MacDowell (2009: p. 191); Harris (2018: p. 149, note 150). 
delayed. ${ }^{74}$ In caput 99, Diodorus masterfully evokes this chaos through a chain of questions, which can also be seen as a summary of his economic arguments. Nevertheless, the point is an exaggeration. Fines could not have been such a major portion of the state's income. While there is some truth in the argument that the deferral may cause delays in payments, Harris's logical statement should be noted: imprisonment did not solve the problem of repayment but hindered it, as citizens could not make money when imprisoned..$^{75}$ The issue of suretyship is connected to this question. Diodorus frames this possibility as a kind of panacea for avoiding imprisonment, while Harris noted the economic rationale behind Timocrates's law. ${ }^{76}$ Diodorus also raises the question of what happens to a convicted citizen who does offer surety? ${ }^{77}$ The argument is almost ridiculous; such a person would remain in prison according to the laws.

Finally, at the end of the first half of his speech, Diodorus summarises his legal and political arguments. From this point onwards, the speech aims to prove the premeditated, malicious intent of the law. This is done by reinforcing the oligarchic and religious arguments and illustrating how rotten the character of those who would benefit from Timocrates's law is, and drawing Timocrates's character into question.

\section{Sacral arguments}

The day the law was proposed - 12 Hecatombaion - is problematic in terms of the sacral arguments as well. The day was the Feast of Cronos when Athenians celebrated the memory of the Golden Age. The Boule could not meet on the day, but this seems not to have applied to the Ecclesia. ${ }^{78}$ Diodorus's wording suggests the same interpretation. First, he merely states that the Council could not meet during the Cronia. After summarising Epicrates's decree, he acts as if the prohibition had applied to all public affairs, including the legislature, meaning Timocrates committed a crime and a sacral transgression.

\footnotetext{
"Anyone could understand this by examining what has been said so far. His refusal to observe the time set by law and his efforts to take away your opportunity to deliberate and reflect before he passed his law during the holy truce are not his only crimes. He also committed another crime, which was to introduce a law that violates all the established laws."79
}

74 Dem. 24.91-94., 96-101.

75 Dem. 24.93-94., cf. Harris (2018: pp. 109-110).

76 Dem. 24.84-85., 87.

77 Dem. 24.88-89.

78 Martin (2009: p. 132) considers it likely on the basis of Aeschin. 3.67. Canevaro (2013: p. 112); Harris (2018: p. 128, note 83) does not.

79 Dem. 24.32., cf. 24.26. The same argument appears in caput 47. 
Thus, Timocrates did not, in fact, commit a sacral transgression, yet Diodorus aims to maintain the appearance of one ${ }^{80}$ However, considering that Timocrates submitted and pushed through his proposal by citing the holiest festival in Athens, the Panathenaea, while the proposal had nothing to do with the festival, the question of a sacral transgression can be raised on firmer ground. What is more, because amendments to debts owed to the state would have required the council's approval, which could not have met on the Feast of Cronos, Diodorus's third legal argument also gains sacral connotations.

Among his political arguments, Diodorus raised a sacral argument in connection with the overruling of court decisions: the oath taken by jurors. ${ }^{81}$ In doing so, he wants to reinforce the appearance that the Ecclesia has less authority than the courts. This juxtaposition returns in the second half of the speech. Diodorus assumes that Timocrates will try to derive the spirit of his law, the possible commutation of prison sentences, from the oath taken by the members of the Boule. To refute this, Diodorus quotes the oath, emphasising that it does not include any passages blocking members of the council from imposing prison sentences. ${ }^{82}$

Nearing the end of his legal and political arguments, when Diodorus openly states that Timocrates deserves to be executed for the first time, he summarises the profane and sacral arguments made so far:



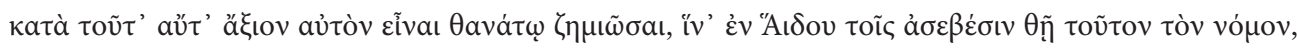

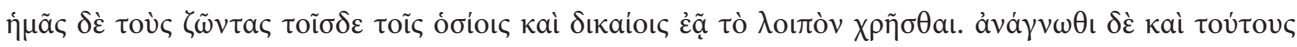

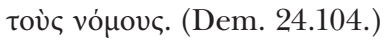

"As a result, in my opinion - what I am about to say may appear rather coarse, but I will say it and not change my mind - for this reason alone he deserves death as a punishment so that he can pass this law in Hades for the sacrilegious and allow us, the living, to follow our sacred and just laws from now on."

Mentioning the underworld and sacrilegious - à $\sigma \varepsilon \beta \dot{\eta} \varsigma$ - was particularly harsh, possibly coarse. Diodorus likely recognised this, hence his pre-emptive apology. It is not completely clear at this point in the speech why Diodorus is so categorical in his wording. He stated at the beginning of the oration that Androtion is enemy of the gods - $\theta \varepsilon$ iis $\dot{\varepsilon} \chi \theta \rho o$ ó - and has also implied that Androtion did something with the sacred vessels. ${ }^{83}$ So far, all that has been said of Timocrates is that his law is delaying payment to the sacred treasury and that the wording of his law is unclear and may damage the temples. ${ }^{84}$ Further, Diodorus alluded to Timocrates committing a sacral transgression by carrying

80 Dem. 24.31-32., 47.

81 Dem 24.78. On the oath of jurors in general, see Hansen (1999: pp. 182-183), and with sacral considerations in mind, Martin (2009: pp. 77-82).

82 Dem. 24.144-151. The argument is repeated in caputs 190-191. For the oath of the members of the boule, see Rhodes (1972: pp. 194-198).

83 Dem. 24.6., 8.

84 Dem. 24.10., 82. 
out legislative work on the Cronia. However, as Diodorus did not emphasise these arguments, the wording seems especially harsh. However, these arguments are reinforced and fleshed out in the second half of the speech, and thus the sharp wording is given more sense. He is categorical because he wants to underline the nature and severity of Timocrates's misconduct, in accordance with the severity of the Athenian laws that guaranteed that those convicted for religious offences regularly received the death penalty in Athens, ${ }^{85}$ or they see their right of entering the temples of the gods being repealed..$^{86}$

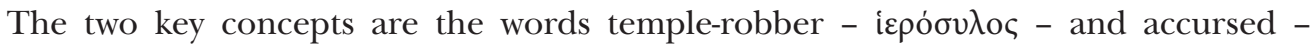

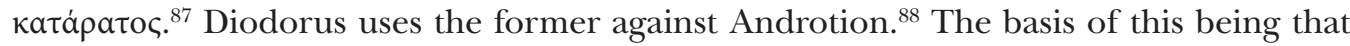
as they did not donate the amount to the treasury of the temples, they essentially stole from the Gods. The case of Androtion is more serious because Diodorus attempts to establish that he had previously committed a sacral transgression by melting down the sacred vessels. However, this is not necessarily true in this form. ${ }^{89} \mathrm{He}$ only uses the word accursed to describe Timocrates for his possible transgression on the Cronia and the exploitation of the provision for the Panathenaea. ${ }^{90}$ The sacral arguments reach their height towards the end of the oration when Diodorus uses the same adjective, enemy of the gods - $\theta \varepsilon$ coí $\mathfrak{\varepsilon} \chi \theta \rho o ́ \varsigma$ - to denote Timocrates just as he had used it to denote Androtion at the beginning of the speech.

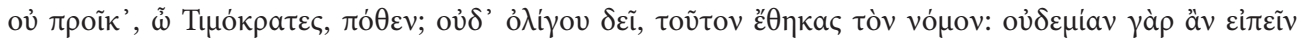

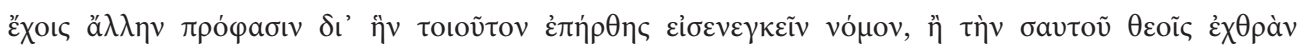

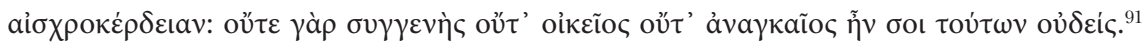

"You did not enact this law without receiving anything in return, Timocrates - how could you? Far from it. There is no other reason you could give that encouraged you to introduce the law than your own god-forsaken greed, for none of these men is your relative, friend, or associate."

Thus, by the end of the speech, Diodorus sees Timocrates and Androtion as a single unit in all respects, having committed the same religious, moral, and political crimes. Thus, Diodorus could hope with good reason that his obfuscation had convinced the jurors of the irreconcilable opposition between Athenian society and Timocrates and Androtion, and of the need to convict Timocrates. ${ }^{92}$

85 Cf. And. 1.68; Dem. 24.7.

86 Cf. And. 1.33; Dem. 23.40.

87 For proof of the religious connotation of the two words see Seres (2020). A statement on pages (pp. 331-332) of the study can be misinterpreted. It may seem as if Timocrates had broken the law by proposing a new law on the Feast of Cronia. However, as seen above the feast is not the root of the transgression, only Diodorus accuses Timocrates of such. Nevertheless, this point does not affect the arguments and findings presented in the paper.

88 Dem. 24.120.

89 Dem. 24.176-182., cf. Harris (1995: pp. 31-36).

90 Dem. 24.107., 198.

91 Dem. 24.195., cf. Dem. 24.6.

92 On religion as a means of unity, division see Martin (2009) and Serafim (2020). 


\section{Moral arguments}

Moral arguments can be divided into two categories. The first intends to prove the amoral character of Timocrates and Androtion and their premeditated, malicious intentions. The second type consists of the arguments that emphasise the responsibility held by the judges.

Diodorus states in the introduction that Timocrates submitted his law deliberately in a premeditated act in the interests of the Androtion and his companions ${ }^{93}$ At the beginning of the speech, Diodorus implies Timocrates did this for financial gain. ${ }^{94}$ However, in the later parts of the speech, which attack Timocrates personally, Diodorus exacerbates the accusation of "simple bribery" with the image of a man, corrupted in both faith and morality, who transgressed against divine laws and aimed to overturn the order of the state - the oligarchic parallels permeating through the entire speech - and was immoral against even his own family. Building on these accusations he tries to isolate his opponent from the civic and moral community of the Athenians, who espouse the values that Timocrates defies. Following the sacral accusations connected to the timing of the proposal and fleshing out the oligarchy parallels, Diodorus aims to negate Timocrates's two main possible counterarguments towards the end of his legal argumentation. The first is that Timocrates proposed the law, not because of his friends or family, and not under duress, but voluntarily to favour Androtion and his companions, and must have been aware that it was unlawful as a citizen well-versed in public affairs. ${ }^{95}$ Diodorus paints an increasingly negative picture of Timocrates. He suggests that Timocrates is trying to mislead the jurors and is thus unworthy of their sympathy and understanding. These points were important in the question of his possible punishment. Diodorus aims to have a severe punishment imposed through the second half of the speech..$^{96}$ The section is defined by the person of Timocrates, and the oligarchy parallels formulated in the first half of the speech ${ }^{97}$ In the intermediate section, Diodorus groups his arguments around two points. He aims to fully blur the line between Androtion's earlier activities or crimes in Diodorus's interpretation - and the person and deeds of Timocrates. ${ }^{98}$ The most prominent tool to this end is a detailed enumeration of the sacral and oligarchic sins they had previously committed when working together. Diodorus also briefly notes the crimes of Melanopus and Glaucetes ${ }^{99}$ and the immoral behaviour Timocrates had displayed toward his own family: he did not support his father in paying a public debt

93 Dem. 24.2., 9. The argument can be found in several part of the speech, cf. Dem. 24.48., 59., 66-67., 107., 110-112., 119., 138., 155-159., 188., 200., 204-206.

94 The argument is used in both the introduction and conclusion of the speech: Dem. 24.3., 122., 195., 200.

95 Dem. 24.66-67. The arguments are repeated in caput 195.

96 Dem. 24.110-214.

97 Dem. 24.110-116., cf. Dem. 24.204-214.

98 Especially Dem. 24.155-159., 170-171.

99 Dem. 24.126-130. 
and simply sold his sister. ${ }^{100} \mathrm{He}$ uses these transgressions to give further colour to the negative profile he is building of Timocrates. In addition, Diodorus tries to refute the possible counterarguments, one of which has moral connotations. Diodorus rightly assumes that Timocrates will argue that the laws must be lenient and fair. This is a strong counterargument, one Diodorus simply cannot refute, as he was unable to prove - despite his efforts - that the law discriminated in favour of Androtion and his companions in any way. ${ }^{101}$

The responsibility of the jurors runs through the speech. Diodorus addresses the

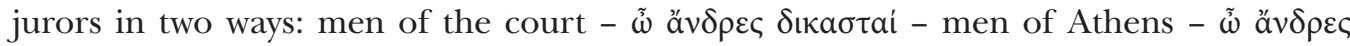

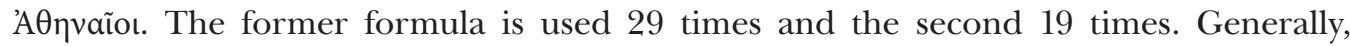
orators would use the former to address jurors in the courts, while the latter would be used to address the Boule or the ecclesia. ${ }^{102}$ The use of both forms of address in Against Timocrates is intentional. Serafim convincingly argues that the form of address is a strategic issue: it denotes the role of the audience in examining the question. Are they acting as jurors, or more broadly, Athenian citizens? ${ }^{103}$ This distinction is particularly obvious in the second half of the speech. When Diodorus contrasts Timocrates with Solon and then Androtion and his companions with recent politicians and proposes a severe punishment on this basis, the form of address men of the court is uttered 22 times, while men of Athens is not used once. ${ }^{104}$ In the last quarter of the speech, where the juxtaposition of democracy and oligarchy, the characteristics of a good politician and the reputation of Athens come to the fore, the more general address, men of Athens, is repeated several times. ${ }^{105}$ The following excerpt, in which both forms appear, illustrates Diodorus's strategy well:

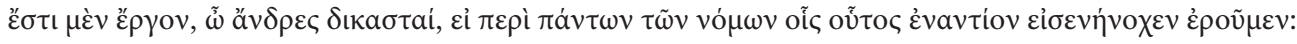

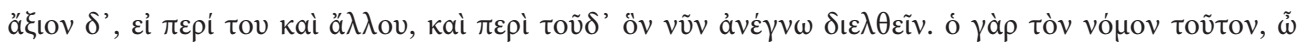

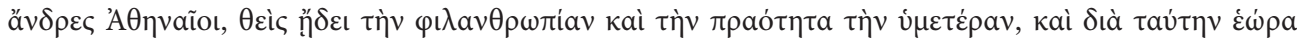

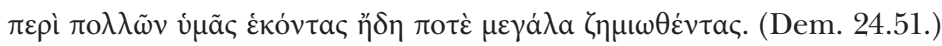

"It would be quite a task, men of the court, for me to discuss all the laws this man has violated by introducing his law. But if any of these deserves analysis, it is the law that I have just now read. The man who enacted this law, men of Athens, understood your generosity and mild nature. He also saw that many times you had willingly caused yourselves serious harm because of these qualities."

100 Dem. 24.202-203. This charge seems to be a topos in oratory, cf. Aeschin. 1.102-105. with Fischer (2001: pp. 239-242).

101 Dem. 24.192-193.

102 For a summary of the techniques used to address the audience, see Martin (2006); and Serafim (2017) following in the former's footsteps.

103 Serafim (2017: pp. 28-30). For a wider context see Serafim (2021).

104 Dem. 24.111-154., cf. Martin (2006: p. 83); Serafim (2017: pp. 38-39).

105 Dem. 24.162-209. 10 times, while men of the court only twice, cf. Serafim (2017: pp. 39-40). 
When speaking about the legal process, he addresses the court as men of the court, and some severity can be heard behind the form. When Diodorus speaks about the goodwill of the jurors, being exploited by Timocrates, ${ }^{106}$ he addresses them as men of Athens. The simultaneous use of both addresses to the audience indicates that the speaker may aim to signal the association between the judicial and political identities of the Athenians in court. They bear both identities and the one, the judicial, affects the other, the civic, and vice versa. As Diodorus moves through the legal and then political arguments, he emphasises the responsibility of the jurors increasingly fiercely until he finally arrives at the specific punishment, which then becomes a defining issue of the second part of the speech. $^{107}$

Diodorus exaggerates right at the beginning of the speech and places a huge amount of responsibility on the jurors. In his interpretation, they must decide whether the rule of law, that is, the order of the democratic state or the law that threatens it, should remain in force. ${ }^{108}$ He later stresses their responsibility, speaking of the jurors as guardians of the law. ${ }^{109}$ At the end of the speech, Diodorus extends their responsibility even further: they are guardians of the state and the guardians of Athens' reputation. He speaks about how the laws of Athens serve as an example to other states. Thus, if the jurors do not condemn people like Timocrates, they themselves will deprive the city of its international esteem:

"You must, therefore, take seriously the task of making the laws seem as good as possible and punishing those who damage and distort them. If you neglect this task, you will lose this source of pride and give the city a bad reputation." 110

As seen above, throughout the speech Diodorus pays special attention to painting Timocrates - and his companions - as people who are working to undermine the functioning of the courts and himself as someone who respects democracy and the courts, moreover, is their guardian. The antipathy felt towards Timocrates and positioning himself as honourable are important factors in deciding the severity of the punishment. Here Diodorus follows what could be called a reversed path: he first names the sentence he would see fitting and then gradually generalises it. At the end of his legal arguments, Diodorus clearly states that Timocrates deserves to die. ${ }^{111}$ He repeats this statement, call-

106 The contrast also appears in caput 53.

107 Dem. 24.53., 78., 95., 101., 104.

108 Dem. 24.5.

109 Dem. 24.36-37.

110 Dem. 24.210. The argument is repeated in caputs 215 and 216. The seeds of this idea appear a little earlier in the speech when Diodorus accuses Androtion of bringing dishonour on the state and citizens of Athens by melting down the votive wreaths, cf. Dem. 24.183-186. The idea that the decisions of the courts influence Athens's reputation are recurrent themes in the orations, cf. Lys. 14.13; 28.15; [Lys.] 6.5., 7., 18; Lyc. 1.14., 114; Hyp. 5.22. cites Harris (2018: p. 152, note 156).

111 Dem. 24.104. In Caput 95, Diodorus mentions any punishment, but as he addresses these words to Timocrates and not the jurors, the section is not relevant to this point. In Caput 101, emphasising the 
ing for the death penalty, the most severe form of punishment, six times in the second half of the speech. ${ }^{112}$ Towards the end of the speech, however, he no longer words this so clearly. His attitude becomes more moderate, as he has argued at length that Timocrates is working to limit the powers of the courts. Thus, it would seem strange for him to continue pushing his requested punishment.

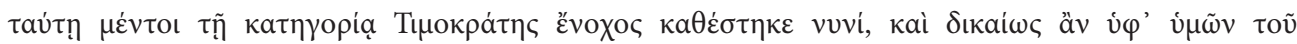

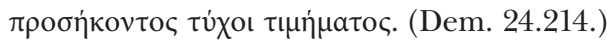

"Timocrates is right now subject to this charge; it would be just for him to suffer the appropriate penalty."

The closing lines of the speech seem even more restrained:

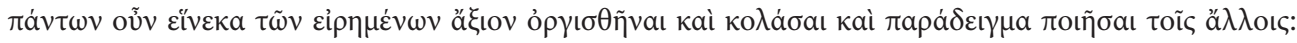

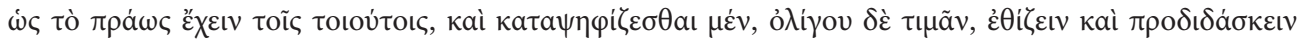

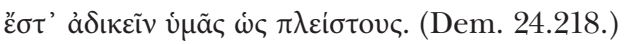

"For all the reasons stated, therefore, you should show your anger and punish this man as an example for others. To show indulgence to men like this by finding them guilty but assessing a small penalty is a way of teaching as many of you as possible the habit of committing crimes."

The structure - anger, punishment, deterrence - could have been effective in encouraging the jurors to pass a judgement worthy of the crimes, and to deter others from proposing similar laws. Although the goal of deterrence obviously alludes to severe punishment, it does not directly specify one, thus respecting the jurors' right to decide.

\section{Summary}

Based on structures that span the whole speech: the juxtaposition of democracy and oligarchy; the sacral arguments; the jurors' responsibility; the depictions of character, the repetition in the opening and closing sections of the speech show that the second half of Against Timocrates is a meticulously edited, well-planned work, and is organically connected to the rigidly structured first half. Even though he phrased a strong criticism of the speech, MacDowell defined the function behind the more fluid structure perfectly. ${ }^{113}$ In the second half of the speech, Diodorus seeks to present several aspects of the

responsibility of the jurors, Diodorus speaks of a worthy punishment that can serve as a deterrent. To this extent, proposing a death sentence up front is an exaggeration.

112 Dem. 24.119., 153., 171., 177., 202., 207. Every occurrence is restrained - the imperative is avoided entire-

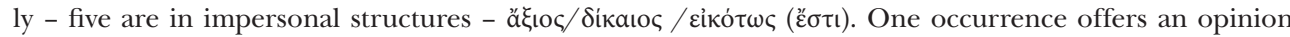
$($ voui $\zeta \omega)$.

113 MacDowell (2009: p. 195): "But the second half of the speech seems to fall to pieces - or rather, to contain pieces which have never been put together. Although it includes many short passages which are individually effective, there is a lack of systematic arrangement. Is this intentional? Is Demosthenes here experimenting with another new technique which he will perfect in later speeches - the technique of 
lawsuit to the jurors at nearly the same time. Necessarily, this results in rapid changes of subject, as he must simultaneously maintain the conclusions drawn from legal and political arguments to ensure that Timocrates's law is repealed and convince the judges of Timocrates's premeditated malicious intentions through his political, sacral, and moral arguments. This paper proves that arguments of different natures could have relevance from a legal point of view, as Rhodes and Harris have pointed out. ${ }^{114}$ The above support Rhodes's and Harris's positions and provide a case-study of how a speech could be constructed to ensure that the arguments are wide-ranging in method and relevant from a legal point of view.

\section{Bibliography}

Badian, E. (2000). The road to prominence. In I. Worthington (Ed.), Demosthenes. Saatesman and Orator (pp. 9-44.) London - New York: Routledge.

Blass, F. (1887-1898). Die attische Beredsamkeit. ${ }^{2}$ Leipzig: Teubner.

Canevaro, M. (2013). The Documents in the Attic Orators. Laws $\mathcal{E}$ Decrees in the Public Speeches of the Demosthenic Corpus. Oxford: University Press.

Canevaro, M. (2016). The Procedure of Demosthenes' Against Leptines: How to Repeal (And Replace) an Existing Law. Journal of Hellenic Studies, 136, 39-58.

Canevaro, M. (2018). The Authenticity of the Document at Demosth. or. 24.20-3, the Procedures

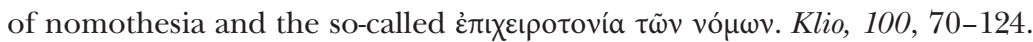

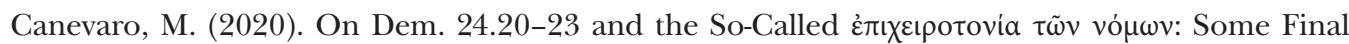
Clarifications in Response to M. H. Hansen. Klio, 102, 26-35.

Cargill, J. (1981). The Second Athenian League. Empire or Free Alliance? Berkeley - Los Angeles - London: University of California Press.

Cawkwell, G. (1962). Notes on the Social War. Classica et Mediaevalia, 23, 34-49.

Develin, R. (2003). Athenian Officials 684-321 BC. Cambridge: University Press.

Fischer, N. (2001) Against Timarchos. Oxford: University Press.

Hansen, M. H. (1979). Did the Athenian Ecclesia Legislate after 403/2 B.C.? Greek, Roman, and Byzantine Studies, 20, 27-53.

Hansen, M. H. (1999). The Athenian Democracy in the Age of Demosthenes. Structure, Principles and Ideology. Norman: University of Oklahoma Press.

Hansen, M. H. (2016). The Authenticity of the Law about Nomothesia inserted in Demosthenes Against Timokrates 20-23. Greek, Roman, and Byzantine Studies, 56, 438-474.

Hansen, M. H. (2019). The Inserted Document at Dem. 24.20-23. Response to Mirko Canevaro. Klio, 101, 452-472.

Harding, P. (1976). Androtion's Political Career. Historia, 25, 186-200.

Harris, D. (1995). The Treasures of the Parthenon and Erechtheion. Oxford: Clarendon Press.

Harris, E. M. (2013a). The Plaint in Athenian Law and Legal Procedure. In M. Faraguna (Ed.),

moving rapidly from one point to another and back again, in order to keep different aspects of his case constantly before the minds of his audience?"

114 Rhodes (2004); Harris (2013a). 
Archives and archival documents in ancient societies: Legal documents in ancient societies IV, Trieste 30 September - 1 October 2011 (pp. 156-175). Trieste: EUT Edizioni Università di Trieste.

Harris, E. M. (2013b). The Rule of Law in Action in Democratic Athens. New York: Oxford University Press.

Harris, E. M. (2018). Demosthenes Speeches 23-26. Austin: Texas University Press.

Hornblower, S. (1982). Mausolus. Oxford: Clarendon Press.

Lane Fox, R. (1997). Demosthenes, Dionysius and the Dating of Six Early Speeches. Classica et Mediaevalia, 48, 167-203.

MacDowell, D. M. (2009). Demosthenes the Orator. Oxford: University Press.

Maffi, A. (2005). Family and Property Law. In M. Gagarin, \& D. Cohen (Eds.), The Cambridge Companion to Ancient Greek Law (pp. 254-266). Cambridge - New York: Cambridge University Press.

Martin, G. (2006). Forms of Address in Athenian Courts. Museum Helveticum, 63, 75-88.

Martin, G. (2009). Divine Talk. Religious Argumentation in Demosthenes. New York: Oxford University Press.

Navarre, O., \& Orsini, P. (1954). Démosthènes, Plaidoyers politiques (Tome I). Paris: Les Belles Lettres.

Németh, Gy. (2006). Kritias und die Dreissig Tyrannen. Untersuchungen zur Politik und Prosopographie der Führungselite in Athen 404/403 v. Chr. Stuttgart: Franz Steiner Verlag.

Pecorella Longo, Ch. (2004). Il condono della pena in Atene in eta classica. Dike, 7, 85-111.

Radicke, J. (1995). Die Rede des Demosthenes für die Freiheit der Rhodier. Stuttgart - Leipzig: Teubner.

Rhodes, J. P. (1972). The Athenian Boule. Oxford: Clarendon Press.

Rhodes, J. P. (2004). Keeping to the Point. In E. M. Harris, \& L. Rubinstein (Eds.), The Law and the Courts in Ancient Greece (pp. 137-158). London: Duckworth.

Rhodes, J. P. (2006). A History of the Classical Greek World 478-323 BC. Malden: Blackwell Publishing.

Rhodes, J. P., \& Osborne, R. (Eds.). (2007). Greek Historical Inscriptions: 404-323 BC. Oxford: Oxford University Press.

Rubinstein, L. (2005). Differentiated rhetorical strategies in the Athenian courts. In M. Gagarin, \& D. Cohen (Eds.), The Cambridge Companion to Ancient Greek Law (pp. 129-145). Cambridge New York: Cambridge University Press.

Schaefer, A. (1885-1887). Demosthenes und seine Zeit. ${ }^{2}$ Leipzig: Teubner.

Sealey, R. (1993). Demosthenes and his Time. A Study in Defeat. Oxford: University Press.

Serafim, A. (2017). 'Conventions' in/as Performance: Addressing the Audience in Selected Public Speeches of Demosthenes. In S. Papaioannou, A. Serafim, \& B. da Vela (Eds.), The Theatre of Justice (Mnemosyne Supplements, 403; pp. 26-41). Leiden - Boston: Brill.

Serafim, A. (2020). Religious Discourse in Attic Oratory and Politics. London: Routledge.

Serafim, A. (2021). "I, He, We, You, They": Addresses to the Audience as a Means of Unity/Division in Attic Forensic Oratory. In A. Michalopoulos, A. Serafim, F. Beneventano della Corte, \& A. Vatri (Eds.), The Rhetoric of Unity and Division in Ancient Literature (pp. 71-98). Berlin Boston: De Gruyter.

Seres, D. (2020). Religious Vocabulary in Demosthenes' Speech Against Timocrates. Acta Classica Universitatis Scientiarum Debreceniensis, 56, 327-340.

Wayte W. (1893). Demosthenes Against Androtion and Against Timocrates with Introductions and English Notes. Cambridge: University Press. 
Dániel Seres

Argumentation in Demosthenes's speech Against Timocrates

Seres Dániel / d.seres@gmail.com

PhD candidate

Department of Ancient History

Eötvös Loránd University, Faculty of Humanities

Múzeum krt. 6-8, 1088 Budapest, Hungary 